\title{
Secondary Nasopharyngeal Mixed Adenoneuroendocrine Carcinoma After Radical Radiotherapy for Nasopharyngeal Carcinoma: A Rare Case and Literature Review [Corrigendum]
}

Huang D, Huang C, Wang H, et al. Onco Targets Ther. 2021;14:1367-1376.
The authors apologize for this error and advise it does not affect the results of the paper.

The authors have advised due to an error at the time of figure assembly, Figure 4F on page 1373 is incorrect. The correct Figure 4 is shown below.

A Hematoxylin and eosin $(\times 5)$

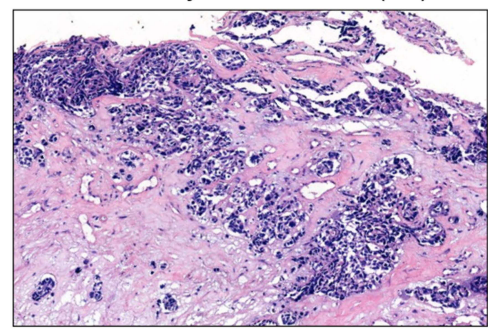

D

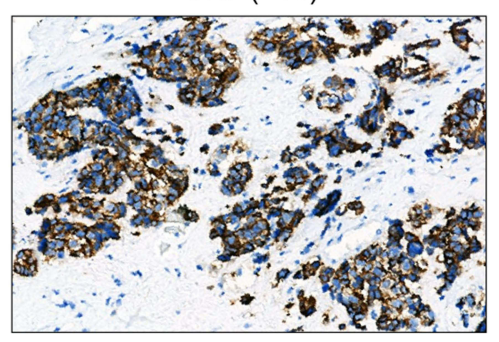

G

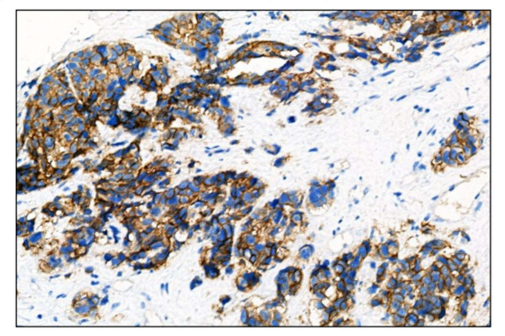

B

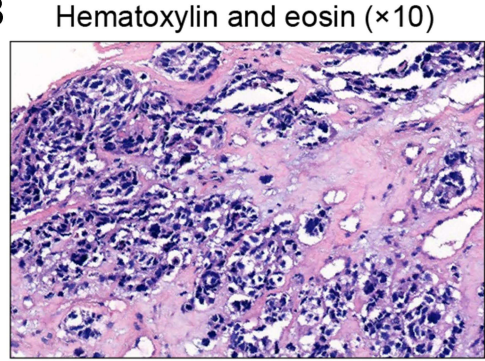

$\mathbf{E}$

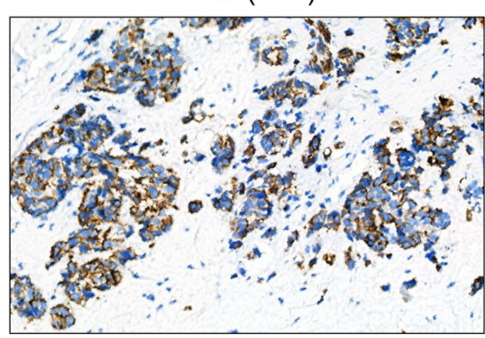

H

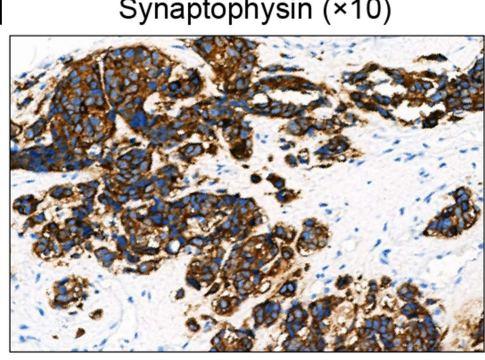

C

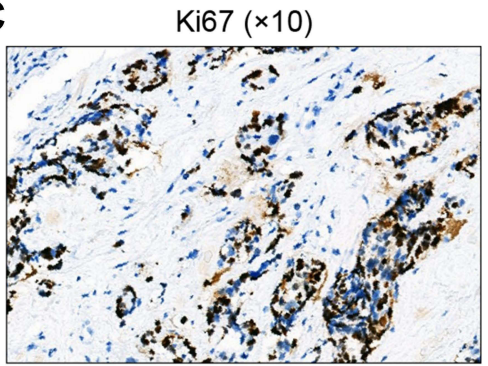

$\mathbf{F}$

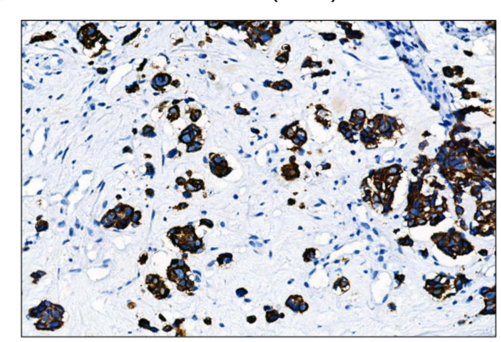

I

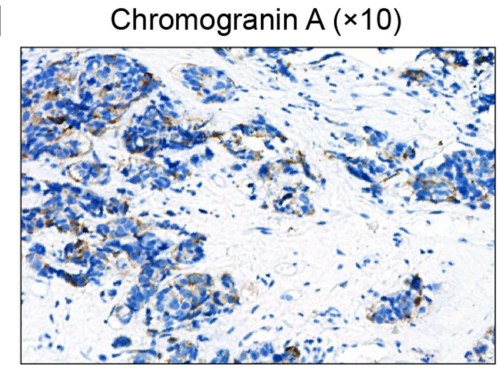

Figure 4 Histological analysis of the first external auditory canal biopsy. (A, B) Hematoxylin and eosin-stained slides showing some glandular structures in poorly differentiated tumor cells. (C-I) Immunohistochemical staining showing elevated proliferation rates (>90\% hotspot Ki-67) (C), and simultaneous expression of CK7 (D), CK8 (E), CKI8 (F), CD56 (G), synaptophysin (H), and chromogranin A (I) in > 50\% of the tumor cells. Magnifications: a, ×5; b-i, $\times 10$. 


\section{Publish your work in this journal}

OncoTargets and Therapy is an international, peer-reviewed, open access journal focusing on the pathological basis of all cancers, potential targets for therapy and treatment protocols employed to improve the management of cancer patients. The journal also focuses on the impact of management programs and new therapeutic agents and protocols on patient perspectives such as quality of life, adherence and satisfaction. The manuscript management system is completely online and includes a very quick and fair peer-review system, which is all easy to use. Visit http://www.dovepress.com/ testimonials.php to read real quotes from published authors.

Submit your manuscript here: https://www.dovepress.com/oncotargets-and-therapy-journal 